\title{
Human basal body basics
}

\author{
Anastassiia Vertii ${ }^{1}$, Hui-Fang Hung ${ }^{1}$, Heidi Hehnly ${ }^{2}$ and Stephen Doxsey ${ }^{1 *}$
}

\begin{abstract}
In human cells, the basal body (BB) core comprises a ninefold microtubule-triplet cylindrical structure. Distal and subdistal appendages are located at the distal end of $\mathrm{BB}$, where they play indispensable roles in cilium formation and function. Most cells that arrest in the $G_{0}$ stage of the cell cycle initiate BB docking at the plasma membrane followed by BB-mediated growth of a solitary primary cilium, a structure required for sensing the extracellular environment and cell signaling. In addition to the primary cilium, motile cilia are present in specialized cells, such as sperm and airway epithelium. Mutations that affect BB function result in cilia dysfunction. This can generate syndromic disorders, collectively called ciliopathies, for which there are no effective treatments. In this review, we focus on the features and functions of BBs and centrosomes in Homo sapiens.
\end{abstract}

Keywords: Basal body, Cilium, Centrosome, Ciliopathy, Human

\section{Basal body origin and basal body/centrosome cycle}

Most cell types in humans have a single primary cilium that protrudes from the cell surface when the cell arrests in the $\mathrm{G}_{0}$ cell cycle stage. The basal body (BB) forms the base of the cilium and arises from the mother centriole of the centrosome $[1,2]$. When a cell exits the cell cycle, the mother centriole docks at the plasma membrane and converts into a BB for primary cilium formation [2, 3]. Primary cilium formation is a dynamic process that can be reverted under mitogenic conditions. Cilia disassembly is a poorly understood process that occurs when the cell re-enters the cell cycle. Two pathways are involved in this process, namely Nek2-Kif24 and AuroraA-HDAC6 [4]. When the cell re-enters the cell cycle, BBs relinquish their function at the base of cilia, and convert to centrosomes/spindle poles [5, 6].

Some specific cell types grow multiple motile cilia that beat synchronously to direct fluid flow, and produce multiple BBs [7]. One example is the mucociliary epithelium in airways, otherwise known as the mucociliary escalator.

\footnotetext{
*Correspondence: Stephen.Doxsey@umassmed.edu

${ }^{1}$ Program in Molecular Medicine, University of Massachusetts Medical

School, Worcester, MA, USA

Full list of author information is available at the end of the article
}

The escalator covers most of the bronchi, bronchioles, and nose, and functions in continuous beating to push unwanted microorganisms and mucus up and out into the throat [8]. Little is known about the mechanism for construction of a BB in multiciliated cells. What is known is that in proliferating cells, centrioles duplicate only once per cell cycle, whereas in multiciliated cells, hundreds of centrioles form almost simultaneously in a de novo pathway. However, a recent study identified an intriguing asymmetry in this pathway: about $90 \%$ of centrioles were synthesized from the daughter centriole of the original centrosome [9]. BBs in these cells are thought to derive from a centrosome-like opaque cytoplasmic structure called the "deuterosome." Two molecular players implicated in this function include the protein Ccdc78 and Ccdc67, and the known centrosome proteins Cep152, Plk4, and SAS-6 [10]. From an evolutionary perspective, all metazoans rely on cytoplasmic de novo BB biogenesis for multiciliation [7]. The importance of de novo BB biogenesis in humans is illustrated in patients mutant for cyclin $\mathrm{O}$. When this regulator of de novo BB biogenesis is mutated, patients exhibit progressive defects in the respiratory tract but lack the classical ciliopathy phenotype $[11,12]$.

During spermatogenesis, BBs are produced together with sperm metamorphosis in an interesting way. In 
Homo sapiens, round spermatids undergo a complex differentiation process that results in mature spermatozoa. In spermatozoa, the sole function of the centriole is seemingly to template the motile cilium/flagellum. Since spermatids will not enter a new mitotic cycle, their centrosomes undergo a functional shift to BBs that serve as templates for the assembly of the flagellum. Centrosome reduction then occurs. This process includes loss of the pericentriolar material (PCM) and the ability to nucleate microtubules $[13,14]$. All together, humans possess a complex arsenal of mechanisms to regulate the BB, although the idiosyncrasies between cell types that regulate these processes are unknown.

\section{Review}

\section{Basic basal body structure and sub-structures}

The mother centriole of the centrosome serves as a physical template for human cilia formation (reviewed by Bornens 2012 [15]). The centrosome consists of a pair of MT-based centrioles (the mother/older and daughter), pericentriolar material, and pericentriolar satellites [16] (Fig. 1a). The centriole consists of 9 triplet microtubules on its proximal end, and 9 doublet microtubules on its distal end [17-20]. At the center of the centriole is a cartwheel structure with a central hub, which organizes the ninefold symmetric MT centriole wall. CEP135 at the centriole wall links with SAS-6 at the cartwheel hub [21] (Fig. 1b). Distal ends of the BBs/mother centrioles posses two sets of appendages, namely distal (DAP) and subdistal (SAP) appendages. Human BBs and centrosomes contain five types of tubulin: $\alpha, \beta, \gamma, \delta$, and $\varepsilon$ [22]. While MT polymers consist exclusively of $\alpha$ - and $\beta$-tubulin heterodimers; $\gamma$-tubulin is integrated into $\gamma$-tubulin ring complexes ( $\gamma$-TURCs), which are responsible for MT nucleation [23-26]. $\varepsilon$-Tubulin associates with sub-distal appendages of the centrioles and is critical for centriole duplication and MT organization [27, 28].

DAPs (also called "transition fibers" in cilia) dock BBs at the plasma membrane and initiate ciliogenesis [29-31]. DAPs initiate ciliogenesis by mediating the formation of the ciliary vesicle through Rab GTPases [32] and IFT20 [33], both of which are important vesicle trafficking components [34-36]. C2cd3, which localizes to the distal end of the $\mathrm{BB}$, is required for DAP formation [37]. During DAP assembly, Cep83 is required for recruitment of multiple DAP proteins including Cep89 (Cep123), SCLT2, FBF1, and Cep164 [30]. Cep164 is a multifunctional DAP protein that orchestrates several events during early ciliogenesis. For example, Cep164 is indispensible for ciliary vesicle formation $[38,39]$, and $\mathrm{BB}$ docking at the plasma membrane [29, 38]. Moreover, Cep164 directly recruits tau tubulin kinase-2 (TTBK2) to the BB [40], where it is critical for CP110 removal from the BB-an important prerequisite for ciliogenesis [41, 42]. These observations suggest that Cep164 mediates not only the BB-membrane docking step, but also coordinates ciliogenesis. In addition to Cep164, Cep89 (Cep123) participates in ciliary vesicle formation [43]. Consistent with a DAP role in ciliogenesis is the evidence that mutations in DAP proteins such as C2cd3 [44], Cep83 [45], Cep164 [46], and SCLT1 [47] result in ciliopathies.

SAPs (also called "basal feet" in cilia) are involved in MT anchoring [48] (Fig. 1a), and were not considered to be involved in cilia function until recently. (1) Mutations in SAP proteins have now been shown to cause ciliopathies [49-51]. (2) The SAP proteins, cenexin and centriolin, are specifically required for recycling endosome trafficking and ciliogenesis [34, 52, 53]. (3) SAPs and the ciliopathy protein complex, the BBSome [54] are connected in the sense that BBS4 is required for MT anchoring. The BBSome is a 7-protein complex that is associated with the ciliopathy, Bardet-Biedl syndrome [55]. Based on this evidence, SAPs, as BB sub-structures, may be involved in ciliary functions.

Pericentriolar satellites are dynamic dynein and kinesin-driven electron-dense granules located within and around the pericentriolar material (PCM) [56, 57]. Satellites consist of dozens of proteins, many of which are required for cilia formation [57]. This suggests that satellites modulate ciliogenesis, although their precise role in this process remains elusive [36, 57]. Recent evidence suggests that the satellite proteins, Cep290 and PCM1, are involved in ciliogenesis through modulating Rab8 recruitment to $\mathrm{BBs}[58,59]$. In addition, recent studies demonstrate that autophagy, a process that turns over cellular debris, can promote ciliogenesis by degrading select centriolar satellite proteins such as OFD1 [60, 61]. OFD1 is localized to SAPs and pericentriolar satellites and is responsible for recruitment of Cep290 to these sites [62]. These results suggest that satellites are active BB substructures that contribute to ciliopathy pathogenesis when disrupted [63].

Another transient $\mathrm{BB}$ substructure, the ciliary vesicle (Fig. 1a, c), appears first as small vesicles that accumulate at DAPs of the BB before primary cilia formation. These vesicles appear to fuse to form a ciliary vesicle "cap." The $\mathrm{BB}$ and associated cap is thought to move up to and fuse with the plasma membrane allowing the cilium to grow and extend out into the extracellular space. A ciliary pit is created after the cilium is fully made through an interaction between the ciliary vesicle membrane and DAPs [64] (Fig. 1c, stages 4 and 5). Upon exit from $G_{0}$ and primary cilia disassembly, cilia components and cilia membrane are inherited by the mother centriole. Strikingly, these components seem to be retained at the oldest spindle pole (the pole containing the mother/oldest centriole) when 


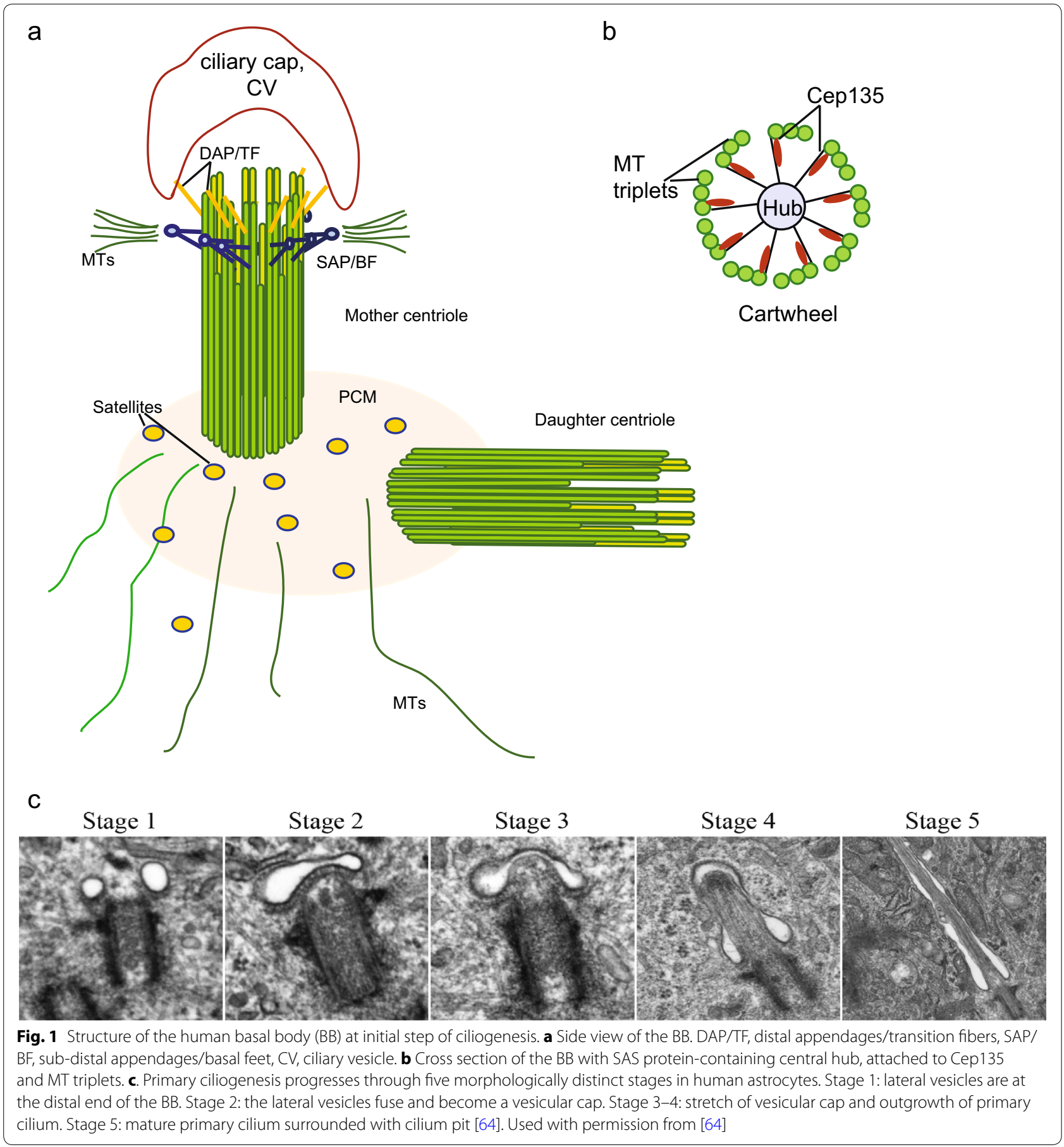

the cell divides again [65]. The daughter cell that contains the oldest spindle pole and the inherited ciliary membrane components re-establishes a primary cilium earlier than the cell that lacks these ciliary components. These studies imply that the centrosome-associated ciliary membrane functions in temporal control of ciliogenesis [65].
During cilia assembly, the BB facilitates formation of the ciliary rootlet [66]. This structure is formed by oligomers of the protein, rootletin, [67-69], which provides support for the cilium. Besides its function at the base (proximal end) of the $\mathrm{BB}$, rootletin is also a component of the centrosome during G1 and S cell cycle stages and 
is required for centrosome cohesion [70]. Taken together, human BBs are equipped with transition fibers (DAPs), the ciliary rootlet, and basal feet (SAPs) [22].

\section{Identification of basal body components}

Proteomic analyses of human centrosomes have uncovered many centrosome-associated proteins [71, 72]. BB components were identified in these studies as well as in the cilia proteome [73], in expression studies from cilia in ciliopathy patients [74], and in the spermatozoan proteome [75]. A number of mother-centriole-specific proteins were identified using PCP-SILAC mass spectrometry. Ccdc41 and Cep89 are two recent examples [71]. A latter study confirmed their DAP localization, and their critical roles in ciliary docking to the plasma membrane and subsequent cilia formation [30]. Moreover, a cilia proteomic database, Cildb, is a useful resource for comparing BBs, centrioles, and centrosomes across different organisms $[76,77]$.

\section{Other functions of the basal body}

BBs possess most of the characteristics of centrosomes, including the ability to organize the microtubule cytoskeleton. It appears that one of the major regulatory roles of BBs is coordination of several complicated trafficking pathways. One example is a sub-compartment of the endocytic pathway, called the recycling endosome. Two GTPases are involved in its organization and function, namely Rab8 and Rab11, which are also reported to have an association with the centrosome [34, 53]. Strikingly, these same GTPases have been implicated in early stages of ciliogenesis through a Rab-GTPase cascade [78]. Recycling endosome vesicles modulated by Rab11 are brought to the basal body with the Rab8 guanine nucleotide exchange factor (GEF), Rabin8. It is proposed that once Rab11 vesicles with Rabin8 accumulate at the centrosome, Rabin8 activates Rab8 to initiate ciliogenesis. Two additional known regulators of endocytosis, EHD1 and EHD3, associate with this cascade and influence ciliary vesicle formation at DAPs [32]. These studies suggest that during cilia formation, the centrosome usurps a handful of regulatory proteins to manufacture a cilium.

In addition to GTPase modulation of cilia, proteasomemediated protein degradation is another mechanism by which BBs/centrosomes influence ciliogenesis. Although proteasomes are distributed throughout the cell, specific biological functions of the proteasome directly at centrosomes have been reported [79]. In mammalian neurons, proteasomes localized at the centrosome regulate degradation of local ubiquitin conjugates promoting the elaboration of dendrite arbors [80]. Centrosome-localized proteasomes are also responsible for centrosome deconstruction during fever [81]. Recently, BB-localized proteasomes were implicated in ciliogenesis by removal of a negative regulator of ciliogenesis, trichoplein [82]. However, the mechanism of proteasome recruitment to the centrosome and/or BB is unknown.

Although BBs are best defined by their role as the template for cilia formation, they also function in nonciliated human cells. For example, in lymphocytes, the centrosome docks to the plasma membrane via DAPs to form an immune synapse in much the same way as BBs dock to the plasma membrane to form cilia. Depletion of CP110, a negative regulator of ciliogenesis, and its concomitant removal from the mother centriole induces ciliogenesis in these cells, providing evidence that the centrosome at this step is transformed into a BB [83]. In this capacity, BBs facilitate IFT-dependent transport of T-cell receptors to the synapse, and mediate cytolytic granule release into the target cell [84-86].

\section{Notable basal body findings}

Sorokin was among the first to demonstrate the need for basal bodies to interact with membranes and for microtubule growth to be coordinated with membrane extension during ciliogenesis [87]. This interaction between BBs with the plasma membrane requires the Rab GTPase cascade and membrane-shaping proteins [32]. Another significant step in basal body biology was the identification of a great number of human disorders, namely ciliopathies and brain-related disorders, like microcephaly, that are associated with mutations in BB components [11, 51, 74, 88-98]. This, in turn, was paralleled by the realization that centrosome proteins are essential for cilia formation and integrity [29, 31, 99]. Taken together, these findings lay the groundwork for understanding the molecular mechanisms of BB function that contribute to ciliopathies.

\section{Conclusions}

Strength and future of basal body research in humans

Essential efforts toward identification of additional mutations in centrosome/BBs that cause ciliopathies exponentially expand our current knowledge on centrosomes/ BBs. This will both facilitate our understanding of these important structures and, in turn, will help in the design of new therapies for ciliopathies, which currently cannot be cured. For example, obesity and impaired ciliogenesis are key features for patients with BBS. During adipocyte differentiation, a transient primary cilium is formed, and the Wnt and Hedgehog receptors present on this primary cilium can inhibit adipogenesis. This has important implications for patients with BBS, where obesity is perhaps caused through impaired ciliogenesis and Wnt/Hedgehog signaling. Moreover, the activity of adipogenic glycogen synthase kinase 3 (GSK3) is enhanced in BBS patients because Wnt signaling is not available 
to antagonize it. Therefore, pharmacological inhibition of GSK $\beta$ could become a potential treatment for BBS patients [100].

However, the overlapping properties and functions of centrosomes and BBs, and the ability of both to perturb ciliogenesis when disrupted, make it difficult to discern the molecular mechanisms behind ciliopathies. Moreover, it remains to be determined if cilia, centrosomes, and BBs all contribute to the etiology of these disorders [36] and if so, to what extent. Finally, other functions of BBs and centrosomes must be considered in the context of these disorders such as mitotic defects that are caused by cilia proteins [101].

\section{Abbreviations}

BB: basal body; BBS: Bardet-Biedl Syndrome; DAP: distal appendages; IFT: intraflagellar transport; MTs: microtubules; MTOC: microtubule organizing center; PCM: pericentriolar material; SAP: sub-distal appendages; TCR: T cell receptor.

\section{Authors' contributions}

$\mathrm{AV}, \mathrm{H}-\mathrm{FH}, \mathrm{HH}$, and SD wrote the manuscript. AV and SD generated figure. All authors read and approved the final manuscript.

\section{Author details}

${ }^{1}$ Program in Molecular Medicine, University of Massachusetts Medical School, Worcester, MA, USA. ${ }^{2}$ Department of Cell and Developmental Biology, SUNY Upstate Medical University, Syracuse, NY, USA.

\section{Acknowledgements}

We would like to thank Wendy Zimmerman for critical reading of the manuscript. This work was supported by Grants R00GM107355 to H.H and GM 051994 to SJD.

\section{Competing interests}

The authors declare that they have no competing interests.

Received: 26 October 2015 Accepted: 10 February 2016

Published online: 14 March 2016

\section{References}

1. Sorokin S. Centrioles rudimentary and smooth and the formation of cilia muscle by fibroblasts. J Cell Biol. 1962;15:363-77.

2. Vorobjev IA. Chentsov YuS. Centrioles in the cell cycle. I. Epithelial cells. J Cell Biol. 1982:93:938-49.

3. Tateishi K, Yamazaki Y, Nishida T, Watanabe S, Kunimoto K, Ishikawa $H$, Tsukita S. Two appendages homologous between basal bodies and centrioles are formed using distinct Odf2 domains. J Cell Biol. 2013;203:417-25.

4. Kim S, Lee K, Choi J-H, Ringstad N, Dynlacht BD. Nek2 activation of Kif24 ensures cilium disassembly during the cell cycle. Nat Commun. 2015:6:8087.

5. Jackson PK. Do cilia put brakes on the cell cycle? Nat Cell Biol. 2011:13:340-2.

6. Wang W, Wu T, Kirschner MW. The master cell cycle regulator APCCdc20 regulates ciliary length and disassembly of the primary cilium. Elife. 2014;3:e03083.

7. Brooks ER, Wallingford JB. Multiciliated cells. Curr Biol. 2014;24:R973-82.

8. Shah AS, Ben-Shahar Y, Moninger TO, Kline JN, Welsh MJ. Motile cilia of human airway epithelia are chemosensory. Science. 2009;325:1131-4.

9. Al Jord A, Lemaitre A-I, Delgehyr N, Faucourt M, Spassky N, Meunier A. Centriole amplification by mother and daughter centrioles differs in multiciliated cells. Nature. 2014;516:104-7.
10. Klos Dehring DA, Vladar EK, Werner ME, Mitchell JW, Hwang P, Mitchell BJ. Deuterosome-mediated centriole biogenesis. Dev Cell. 2013;27:103-12.

11. Boon M, Wallmeier J, Ma L, Loges NT, Jaspers M, Olbrich H, Dougherty GW, Raidt J, Werner C, Amirav I, Hevroni A, Abitbul R, Avital A, Soferman R, Wessels M, O'Callaghan C, Chung EMK, Rutman A, Hirst RA, Moya E, Mitchison HM, Van Daele S, De Boeck K, Jorissen M, Kintner C, Cuppens $\mathrm{H}$, Omran H. MCIDAS mutations result in a mucociliary clearance disorder with reduced generation of multiple motile cilia. Nat Commun. 2014;5:4418.

12. Funk MC, Bera AN, Menchen T, Kuales G, Thriene K, Lienkamp SS, Dengjel J, Omran H, Frank M, Arnold SJ. Cyclin O (Ccno) functions during deuterosome-mediated centriole amplification of multiciliated cells. EMBO J. 2015;34:1078-89.

13. Manandhar G, Simerly C, Schatten G. Highly degenerated distal centrioles in rhesus and human spermatozoa. Hum Reprod. 2000;15:256-63.

14. Avidor-Reiss T, Khire A, Fishman E, Jo K. Atypical centrioles during sexual reproduction. Front Cell Dev Biol. 2015;3

15. Bornens M. The centrosome in cells and organisms. Science. 2012;335:422-6.

16. Doxsey S. Re-evaluating centrosome function. Nat Rev Mol Cell Biol. 2001:2:688-698.

17. Ibrahim R, Messaoudi C, Chichon FJ, Celati C, Marco S. Electron tomography study of isolated human centrioles. Microsc Res Tech. 2009;72:42-8

18. Sonnen KF, Schermelleh L, Leonhardt H, Nigg EA. 3D-structured illumination microscopy provides novel insight into architecture of human centrosomes. Biol Open. 2012;1:965-76.

19. Bornens M, Paintrand M, Berges J, Marty MC, Karsenti E. Structural and chemical characterization of isolated centrosomes. Cell Motil Cytoskeleton. 1987:8:238-49.

20. Nigg EA, Raff JW. Centrioles, centrosomes, and cilia in health and disease. Cell. 2009:663-678.

21. Lin Y-C, Chang C-W, Hsu W-B, Tang CJ, Lin YN, Chou EJ, Wu CT, Tang TK. Human microcephaly protein CEP135 binds to hSAS-6 and CPAP, and is required for centriole assembly. EMBO J. 2013;32:1141-54.

22. Carvalho-Santos Z, Azimzadeh J, Pereira-Leal JB, Bettencourt-Dias M. Tracing the origins of centrioles, cilia, and flagella. J Cell Biol. 2011;194:165-75.

23. Kollman JM, Merdes A, Mourey L, Agard DA. Microtubule nucleation by $\gamma$-tubulin complexes. Nat Rev Mol Cell Biol. 2011;12:709-21.

24. Stearns T, Evans L, Kirschner M. $\gamma$-Tubulin is a highly conserved component of the centrosome. Cell. 1991;65:825-36.

25. Stearns T, Kirschner M. In vitro reconstitution of centrosome assembly and function: the central role of $\gamma$-tubulin. Cell. 1994;76:623-37.

26. Dictenberg JB, Zimmerman W, Sparks CA, Young A, Vidair C, Zheng Y, Carrington W, Fay FS, Doxsey SJ. Pericentrin and $y$-tubulin form a protein complex and are organized into a novel lattice at the centrosome. J Cell Biol. 1998;141:163-74.

27. Chang P, Stearns T. $\delta$-Tubulin and $\varepsilon$-tubulin: two new human centrosomal tubulins reveal new aspects of centrosome structure and function. Nat Cell Biol. 2000;2:30-5.

28. Chang P, Giddings TH, Winey M, Stearns T. $\varepsilon$-Tubulin is required for centriole duplication and microtubule organization. Nat Cell Biol. 2003:5:71-6.

29. Graser S, Stierhof YD, Lavoie SB, Gassner OS, Lamla S, Le Clech M, Nigg EA. Cep164, a novel centriole appendage protein required for primary cilium formation. J Cell Biol. 2007;179:321-30.

30. Tanos BE, Yang HJ, Soni R, Wang WJ, Macaluso FP, Asara JM, Tsou MFB. Centriole distal appendages promote membrane docking, leading to cilia initiation. Genes Dev. 2013;27:163-8.

31. Mikule K, Delaval B, Kaldis P, Jurcyzk A, Hergert P, Doxsey S. Loss of centrosome integrity induces p38-p53-p21-dependent G1-S arrest. Nat Cell Biol. 2007;9:160-70.

32. Lu Q, Insinna C, Ott C, Stauffer J, Pintado PA, Rahajeng J, Baxa U, Walia V, Cuenca A, Hwang YS, Daar IO, Lopes S, Lippincott-Schwartz J, Jackson PK, Caplan SWC. Early steps in primary cilium assembly require EHD1/EHD3-dependent ciliary vesicle formation. Nat Cell Biol. 2015;17:228-40. 
33. Joo K, Kim CG, Lee MS, Moon HY, Lee SH, Kim MJ, Kweon HS, Park WY, Kim CH, Gleeson JG, Kim J. CCDC41 is required for ciliary vesicle docking to the mother centriole. Proc Natl Acad Sci. 2013;110:5987-92.

34. Hehnly H, Chen CT, Powers CM, Liu HL, Doxsey S. The centrosome regulates the Rab11-dependent recycling endosome pathway at appendages of the mother centriole. Curr Biol. 2012;22:1944-50.

35. Leitch CC, Lodh S, Prieto-Echagüe V, Badano JL, Zaghloul NA. Basal body proteins regulate notch signaling through endosomal trafficking. J Cell Sci. 2014;127(Pt 11):2407-19.

36. Vertii A, Bright A, Delaval B, Hehnly H, Doxsey S. New frontiers: discovering cilia-independent functions of cilia proteins. EMBO Rep 2015:e201540632.

37. Ye X, Zeng H, Ning G, Reiter JF, Liu A. C2cd3 is critical for centriolar distal appendage assembly and ciliary vesicle docking in mammals. Proc Natl Acad Sci USA. 2014;111:2164-9.

38. Schmidt KN, Kuhns S, Neuner A, Hub B, Zentgraf H, Pereira G. Cep164 mediates vesicular docking to the mother centriole during early steps of ciliogenesis. J Cell Biol. 2012;199:1083-101.

39. Burke MC, Li FQ, Cyge B, Arashiro T, Brechbuhl HM, Chen X, Siller SS, Weiss MA, O'Connell CB, Love D, Westlake CJ, Reynolds SD, Kuriyama R, Takemaru KI. Chibby promotes ciliary vesicle formation and basal body docking during airway cell differentiation. J Cell Biol. 2014;207:123-37.

40. Oda T, Chiba S, Nagai T, Mizuno K. Binding to Cep164, but not EB1, is essential for centriolar localization of TTBK2 and its function in ciliogenesis. Genes Cells. 2014;19:927-40.

41. Spektor A, Tsang WY, Khoo D, Dynlacht BD. Cep97 and CP110 suppress a cilia assembly program. Cell. 2007;130:678-90.

42. Chen Z, Indjeian VB, McManus M, Wang L, Dynlacht BD. CP110, a cell cycle-dependent CDK substrate, regulates centrosome duplication in human cells. Dev Cell. 2002;3:339-50.

43. Sillibourne JE, Hurbain I, Grand-Perret T, Goud B, Tran P, Bornens M. Primary ciliogenesis requires the distal appendage component Cep123. Biol Open. 2013;2:535-45.

44. Hoover AN, Wynkoop A, Zeng H, Jia J, Niswander LA, Liu A. C2cd3 is required for cilia formation and hedgehog signaling in mouse. Development. 2008;135:4049-58.

45. Failler M, Gee HY, Krug P, Joo K, Halbritter J, Belkacem L, Filhol E, Porath JD, Braun DA, Schueler M, Frigo A, Alibeu O, Masson C, Brochard K, Hurault De Ligny B, Novo R, Pietrement C, Kayserili H, Salomon R, Gubler MC, Otto EA, Antignac C, Kim J, Benmerah A, Hildebrandt F, Saunier S. Mutations of CEP83 cause infantile nephronophthisis and intellectual disability. Am J Hum Genet. 2014;94:905-14.

46. Chaki M, Airik R, Ghosh AK, Giles RH, Chen R, Slaats GG, Wang H, Hurd TW, Zhou W, Cluckey A, Gee HY, Ramaswami G, Hong CJ, Hamilton BA, Červenka I, Ganji RS, Bryja V, Arts HH, Van Reeuwijk J, Oud MM, Letteboer SJF, Roepman R, Husson H, Ibraghimov-Beskrovnaya O, Yasunaga T, Walz G, Eley L, Sayer JA, Schermer B, Liebau MC, et al. Exome capture reveals ZNF423 and CEP164 mutations, linking renal ciliopathies to DNA damage response signaling. Cell. 2012;150:533-48.

47. Adly N, Alhashem A, Ammari A, Alkuraya FS. Ciliary Genes TBC1D32/ C6orf170 and SCLT1 are Mutated in Patients with OFD Type IX. Hum Mutat. 2014;35:36-40.

48. Delgehyr N, Sillibourne J, Bornens M. Microtubule nucleation and anchoring at the centrosome are independent processes linked by ninein function. J Cell Sci. 2005;118:1565-75.

49. Tallila J, Jakkula E, Peltonen L, Salonen R, Kestilä M. Identification of CC2D2A as a Meckel Syndrome gene adds an important piece to the ciliopathy puzzle. Am J Hum Genet. 2008;82:1361-7.

50. BachmannGagescu R, Ishak GE, Dempsey JC, Adkins J, O'Day D, Phelps IG, GunayAygun M, Kline AD, Szczaluba K, Martorell L, Alswaid A, Alrasheed S, Pai S, Izatt L, Ronan A, Parisi MA, Mefford H, Glass I, Doherty D. Genotype-phenotype correlation in CC2D2A-related Joubert syndrome reveals an association with ventriculomegaly and seizures. J Med Genet. 2012;49:126-37.

51. Otto EA, Hurd TW, Airik R, Chaki M, Zhou W, Stoetzel C, Patil SB, Levy S, Ghosh AK, Murga-Zamalloa CA, van Reeuwijk J, Letteboer SJF, Sang L, Giles RH, Liu Q, Coene KLM, Estrada-Cuzcano A, Collin RWJ, McLaughlin HM, Held S, Kasanuki JM, Ramaswami G, Conte J, Lopez I, Washburn J, Macdonald J, Hu J, Yamashita Y, Maher ER, Guay-Woodford LM, et al. Candidate exome capture identifies mutation of SDCCAG8 as the cause of a retinal-renal ciliopathy. Nat Genet. 2010;42:840-50.
52. Chang J, Seo SG, Lee K, Nagashima K, Bang J, Kim B, Erikson RL, Lee KW, Lee H, Park JE, Lee KS. Essential role of Cenexin1, but not Odf2, in ciliogenesis. Cell Cycle. 2013;12:655-62.

53. Yoshimura SII, Egerer J, Fuchs E, Haas AK, Barr FA. Functional dissection of Rab GTPases involved in primary cilium formation. J Cell Biol. 2007;178:363-9.

54. Kim JC, Badano JL, Sibold S, Esmail MA, Hill J, Hoskins BE, Leitch CC, Venner K, Ansley SJ, Ross AJ, Leroux MR, Katsanis N, Beales PL. The Bardet-Biedl protein BBS4 targets cargo to the pericentriolar region and is required for microtubule anchoring and cell cycle progression. Nat Genet. 2004;36:462-70.

55. Forsythe E, Beales PL. Bardet-Biedl syndrome. Eur J Hum Genet. 2013;21:8-13

56. Zimmerman W, Doxsey SJ. Construction of centrosomes and spindle poles by molecular motor-driven assembly of protein particles. Traffic. 2000;1:927-34.

57. Tollenaere MA, Mailand N, BekkerJensen S. Centriolar satellites: key mediators of centrosome functions. Cell Mol Life Sci. 2015;72:11-23.

58. Kim J, Krishnaswami SR, Gleeson JG. CEP290 interacts with the centriolar satellite component PCM-1 and is required for Rab8 localization to the primary cilium. Hum Mol Genet. 2008;17:3796-805.

59. Kobayashi T, Kim S, Lin YC, Inoue T, Dynlacht BD. The CP110-interacting proteins talpid3 and cep290 play overlapping and distinct roles in cilia assembly. J Cell Biol. 2014;204:215-29.

60. Tang Z, Lin MG, Stowe TR, Chen S, Zhu M, Stearns T, Franco B, Zhong Q. Autophagy promotes primary ciliogenesis by removing OFD1 from centriolar satellites. Nature. 2013;502:254-7.

61. Pampliega O, Orhon I, Patel B, Sridhar S, Díaz-Carretero A, Beau I, Codogno P, Satir BH, Satir P, Cuervo AM. Functional interaction between autophagy and ciliogenesis. Nature. 2013;502:194-200.

62. Lopes CAM, Prosser SL, Romio L, Hirst RA, O'Callaghan C, Woolf AS, Fry AM. Centriolar satellites are assembly points for proteins implicated in human ciliopathies, including oral-facial-digital syndrome 1. J Cell Sci. 2011;124:600-12.

63. Zhang Y, Seo S, Bhattarai S, Bugge K, Searby CC, Zhang Q, Drack AV, Stone EM, Sheffield VC. BBS mutations modify phenotypic expression of CEP290-related ciliopathies. Hum Mol Genet. 2014;23:40-51.

64. Moser JJ, Fritzler MJ, Rattner JB. Primary ciliogenesis defects are associated with human astrocytoma/glioblastoma cells. BMC Cancer. 2009;9:448.

65. Paridaen JTML, Wilsch-Bräuninger M, Huttner WB. Asymmetric inheritance of centrosome-associated primary cilium membrane directs ciliogenesis after cell division. Cell. 2013;155:333-44.

66. Hagiwara H, Aoki T, Ohwada N, Fujimoto T. Development of striated rootlets during ciliogenesis in the human oviduct epithelium. Cell Tissue Res. 1997;290:39-42.

67. Hagiwara H, Harada S, Maeda S, Aoki T, Ohwada N, Takata K. Ultrastructural and immunohistochemical study of the basal apparatus of solitary cilia in the human oviduct epithelium. J Anat. 2002;200:89-96.

68. Hagiwara H, Kano A, Aoki T, Ohwada N. Immunocytochemistry of the striated rootlets associated with solitary cilia in human oviductal secretory cells. Histochem Cell Biol. 2000;114:205-12.

69. Yang J, Liu X, Yue G, Adamian M, Bulgakov O, Li T. Rootletin, a novel coiled-coil protein, is a structural component of the ciliary rootlet. J Cell Biol. 2002;159:431-40.

70. Bahe S, Stierhof Y-D, Wilkinson CJ, Leiss F, Nigg EA. Rootletin forms centriole-associated filaments and functions in centrosome cohesion. J Cell Biol. 2005;171:27-33.

71. Jakobsen L, Vanselow K, Skogs M, Toyoda Y, Lundberg E, Poser I, Falkenby LG, Bennetzen M, Westendorf J, Nigg EA, Uhlen M, Hyman AA, Andersen JS. Novel asymmetrically localizing components of human centrosomes identified by complementary proteomics methods. EMBO J. 2011;30:1520-35.

72. Andersen JS, Wilkinson CJ, Mayor T, Mortensen P, Nigg EA, Mann M. Proteomic characterization of the human centrosome by protein correlation profiling. Nature. 2003;426:570-4.

73. Ostrowski LE, Blackburn K, Radde KM, Moyer MB, Schlatzer DM, Moseley A, Boucher RC. A proteomic analysis of human cilia: identification of novel components. Mol Cell Proteomics. 2002;1:451-65.

74. Geremek M, Bruinenberg M, Ziȩtkiewicz E, Pogorzelski A, Witt M, Wijmenga C. Gene expression studies in cells from primary ciliary 
dyskinesia patients identify 208 potential ciliary genes. Hum Genet. 2011;129:283-93.

75. Martínez-Heredia J, Estanyol JM, Ballescà JL, Oliva R. Proteomic identification of human sperm proteins. Proteomics. 2006;6:4356-69.

76. Arnaiz O, Malinowska A, Klotz C, Sperling L, Dadlez M, Koll F, Cohen J. Cildb: a knowledgebase for centrosomes and cilia. Database 2009. 2009:bap022-bap022.

77. Arnaiz O, Cohen J, Tassin A, Koll F. Remodeling Cildb, a popular database for cilia and links for ciliopathies. 2014:1-10.

78. Westlake CJ, Baye LM, Nachury MV, Wright KJ, Ervin KE, Phu L, Chalouni C, Beck JS, Kirkpatrick DS, Slusarski DC, Sheffield VC, Scheller RH, Jackson PK. Primary cilia membrane assembly is initiated by Rab1 1 and transport protein particle II (TRAPPII) complex-dependent trafficking of Rabin8 to the centrosome. Proc Natl Acad Sci USA. 2011;108:2759-64.

79. Wigley WC, Fabunmi RP, Lee MG, Marino CR, Muallem S, DeMartino GN, Thomas PJ. Dynamic association of proteasomal machinery with the centrosome. J Cell Biol. 1999;145:481-90.

80. Puram SV, Kim AH, Park HY, Anckar J, Bonni A. The ubiquitin receptor S5a/Rpn10 links centrosomal proteasomes with dendrite development in the mammalian brain. Cell Rep. 2013;4:19-30.

81. Vertii A, Zimmerman W, Ivshina M, Doxsey S. Centrosome-intrinsic mechanisms modulate centrosome integrity during fever. Mol Biol Cell. 2015;26:3451-63.

82. Kasahara K, Kawakami Y, Kiyono T, Yonemura S, Kawamura Y, Era S, Matsuzaki F, Goshima N, Inagaki M. Ubiquitin-proteasome system controls ciliogenesis at the initial step of axoneme extension. Nat Commun. 2014;5:5081.

83. Prosser S, Morrison C. Centrin2 regulates CP110 removal in primary cilium formation. J Cell Biol. 2015;208:693-701.

84. Finetti F, Paccani SR, Riparbelli MG, Giacomello E, Perinetti G, Pazour GJ, Rosenbaum JL, Baldari CT. Intraflagellar transport is required for polarized recycling of the TCR/CD3 complex to the immune synapse. Nat Cell Biol. 2009;11:1332-9.

85. Finetti F, Paccani SR, Rosenbaum J, Baldari CT. Intraflagellar transport: A new player at the immune synapse. Trends Immunol. 2011;32:139-45.

86. Finetti F, Patrussi L, Masi G, Onnis A, Galgano D, Lucherini OM, Pazour $G J$, Baldari CT. Specific recycling receptors are targeted to the immune synapse by the intraflagellar transport system. J Cell Sci. 2014;127(Pt 9):1924-37.

87. Barr FA. Cilia-the masterplan. 2007:2007-2008

88. Shaheen R, Schmidts M, Faqeih E, Hashem A, Lausch E, Holder I, SupertiFurga A, Mitchison HM, Almoisheer A, Alamro R, Alshiddi T, Alzahrani F, Beales PL. A founder CEP120 mutation in Jeune asphyxiating thoracic dystrophy expands the role of centriolar proteins in skeletal ciliopathies. Hum Mol Genet. 2015;24(5):1410-9.

89. Shaheen $R$, Shamseldin $H E$, Loucks CM, Seidahmed MZ, Ansari S, Ibrahim Khalil M, Al-Yacoub N, Davis EE, Mola NA, Szymanska K, Herridge W, Chudley AE, Chodirker BN, Schwartzentruber J, Majewski J, Katsanis N, Poizat C, Johnson CA, Parboosingh J, Boycott KM, Innes AM, Alkuraya FS. Mutations in CSPP1, encoding a core centrosomal protein, cause a range of ciliopathy phenotypes in humans. Am J Hum Genet. 2014;94:73-9.

90. Tuz K, Bachmann-Gagescu R, O'Day DR, Hua K, Isabella CR, Phelps IG, Stolarski AE, O'Roak BJ, Dempsey JC, Lourenco C, Alswaid A,
Bönnemann CG, Medne L, Nampoothiri S, Stark Z, Leventer RJ, Topçu M, Cansu A, Jagadeesh S, Done S, Ishak GE, Glass IA, Shendure J, Neuhauss SCF, Haldeman-Englert CR, Doherty D, Ferland RJ. Mutations in CSPP1 cause primary cilia abnormalities and joubert syndrome with or without Jeune asphyxiating thoracic dystrophy. Am J Hum Genet. 2014;94:62-72.

91. Piane M, Della Monica M, Piatelli G, Lulli P, Lonardo F, Chessa L, Scarano G. Majewski osteodysplastic primordial dwarfism type II (MOPD II) syndrome previously diagnosed as Seckel syndrome: Report of a novel mutation of the PCNT gene. Am J Med Genet Part A. 2009;149:2452-6.

92. Novarino G. Akizu N. Gleeson JG: Modeling human disease in humans. The ciliopathies. Cell; 2011. p. 70-9.

93. Kalay E, Yigit G, Aslan Y, Brown KE, Pohl E, Bicknell LS, Kayserili H, Li Y, Tüysüz B, Nürnberg G, Kiess W, Koegl M, Baessmann I, Buruk K, Toraman B, Kayipmaz S, Kul S, Ikbal M, Turner DJ, Taylor MS, Aerts J, Scott C, Milstein K, Dollfus H, Wieczorek D, Brunner HG, Hurles M, Jackson AP, Rauch A, Nürnberg $P$, et al. CEP152 is a genome maintenance protein disrupted in Seckel syndrome. Nat Genet. 2011;43:23-6.

94. Hussain MS, Baig SM, Neumann S, Nürnberg G, Farooq M, Ahmad I, Alef T, Hennies HC, Technau M, Altmüller J, Frommolt P, Thiele H, Noegel AA, Nürnberg P. A truncating mutation of CEP135 causes primary microcephaly and disturbed centrosomal function. Am J Hum Genet. 2012;90:871-8.

95. Griffith E, Walker S, Martin C-A, Vagnarelli P, StiffT, Vernay B, Al Sanna N, Saggar A, Hamel B, Earnshaw WC, Jeggo PA, Jackson AP, O'Driscoll M. Mutations in pericentrin cause Seckel syndrome with defective ATRdependent DNA damage signaling. Nat Genet. 2008;40:232-6.

96. Digioia SA, Letteboer SJF, Kostic C, Bandah-rozenfeld D, Hetterschijt L, Sharon D, Arsenijevic Y, Roepman R, Rivolta C. FAM161a, associated with retinitis pigmentosa, is a component of the cilia-basal body complex and interacts with proteins involved in ciliopathies. Hum Mol Genet. 2012;21:5174-84.

97. Bandah-Rozenfeld D, Mizrahi-Meissonnier L, Farhy C, Obolensky A, Chowers I, Pe'Er J, Merin S, Ben-Yosef T, Ashery-Padan R, Banin E, Sharon D. Homozygosity mapping reveals null mutations in FAM161A as a cause of autosomal-recessive retinitis pigmentosa. Am J Hum Genet. 2010;87:382-91.

98. Akizu N, Silhavy JL, Rosti RO, Scott E, Fenstermaker AG, Schroth J, Zaki MS, Sanchez H, Gupta N, Kabra M, Kara M, Ben-Omran T, Rosti B, Guemez-Gamboa A, Spencer E, Pan R, Cai N, Abdellateef M, Gabriel S, Halbritter J, Hildebrandt F, Van Bokhoven H, Gunel M, Gleeson JG. Mutations in CSPP1 lead to classical joubert syndrome. Am J Hum Genet. 2014;94:80-6.

99. Jurczyk A, Gromley A, Redick S, San Agustin J, Witman G, Pazour GJ, Peters DJM, Doxsey S. Pericentrin forms a complex with intraflagellar transport proteins and polycystin-2 and is required for primary cilia assembly. J Cell Biol. 2004;166:637-43.

100. Marion V, Stoetzel C, Schlicht D, Messaddeq N, Koch M, Flori E, Danse $J M$, Mandel J-L, Dollfus H. Transient ciliogenesis involving Bardet-Biedl syndrome proteins is a fundamental characteristic of adipogenic differentiation. Proc Natl Acad Sci USA. 2009;106:1820-5.

101. Delaval B, Bright A, Lawson ND, Doxsey S. The cilia protein IFT88 is required for spindle orientation in mitosis. Nat Cell Biol. 2011;13:461-8.

\section{Submit your next manuscript to BioMed Central and we will help you at every step:}

- We accept pre-submission inquiries

- Our selector tool helps you to find the most relevant journal

- We provide round the clock customer support

- Convenient online submission

- Thorough peer review

- Inclusion in PubMed and all major indexing services

- Maximum visibility for your research

Submit your manuscript at www.biomedcentral.com/submit

() Biomed Central 